\title{
ENHANCING STUDENTS' TRANSLATION WORKS: A CASE FOR TRANSLATION TEACHING
}

\author{
Ani Gustini ${ }^{(1)}$, Akhmad Baihaqi ${ }^{(2)}$ \\ Universitas Sultan Ageng Tirtayasa \\ Surel: gustiniani@gmail.com ${ }^{(1)}$, akhmad.baihaqi@untirta.ac.id ${ }^{(2)}$
}

\begin{abstract}
This current study is aiming to investigate the enhancement of students' translation works of both process and result served by the Student Teams Achievement Division as a learning technique. The study was managed in one private university in Banten Province, Indonesia. Classroom action research was used as a method, and 15 students participated in the study as the subject of the research. The data collecting technique was triangulated by using observation, test, and documentation. The result proves that Student Teams Achievement Division may help students to work cooperatively; they can share and discuss the learning material; then, they can support each other. The results also prove that the average score of pre-cycle is 72 while after Student Teams Achievement Division implementation it improves to 81 in cycle I and 85 in cycle II. Both are categorized as Very Good Translation results. Therefore, it proves that Student Teams Achievement Division can significantly enhance students' translation works of both process and result, and it can be served as an alternative way in teaching and learning translation.
\end{abstract}

Keywords: translation work, translation teaching

Submitted: 24 February $2021 \quad$ Revised: 07 March $2021 \quad$ Accepted: 28 March 2021

\section{INTRODUCTION}

In this era, the relations among countries are increasing significantly. People need powerful media in bridging the relation in every area. One of the media here can be served by translation. Translation products in various fields are required. As Rogi (2009) claimed that to fulfill such requirements, linguists and translators play important role in producing reliable translation works in the fastest way.

Some studies claimed that foreign language students, particularly those who major in English, had difficulties in translation class when they face equivalence and context. Equivalence is related to the degree of accuracy of a source text and its target text (Baihaqi, 2017). Students commonly face a real problem with searching for the most appropriate version in the target language. Context, meanwhile, refers to the situation and culture as attached to a source text and its target text. As Ahmad (2009) argues that the problems of differences in language aspects are not solely related to vocabulary, but also the idea of producing system and the way of thinking in the source language. Hatim 
(2014) also stated that students would face not only grammatical and lexical but also cultural aspects in translating the texts.

Based on pre-observation, the student-centered learning process has been challenging to set up. At the beginning of the class, the students are asked to organize themselves before starting the class. However, it does not work at all. In the class, the students are randomly requested to translate the texts of the book entitled Kami Pilih Islam written by Bey Arifin (1995). The materials are discussed for the meetings being researched.

Most of the students face a real problem in organizing the translation process. It shows that some students do not know what they are translating. They are incapable to produce an equivalent meaning that appropriately represents the meaning of the source language. Even, some of them feel nervous.

They have several sources, such as dictionaries, in the classroom. Unluckily, most of the students are not accurate enough to translate such texts. Most of them favor using machine translation and even electronic dictionaries. However, such machine translation is not comprehensive enough to produce the equal words being translated. As Baihaqi \& Mulyana (2021) had previously proved in their works.

In a classroom session, only a few students convey the questions. To avoid being ashamed, some of them work individually which is not suggested by the student-centered learning process. One of the characteristics is that the student works cooperatively and collaboratively (Ormrod, Anderman, \& Anderman, 2006). In this way, all of the students are helping each other.

Another bad habit is that student only searches for just meaning for the word that they have no idea of it. Some students prove to be poor in the Indonesian Language. They replace the incorrect equivalent meaning. They have serious problems in correspond an appropriate version of the target language, subsequently.

This kind of unsuccessful class requires a solution. If the condition is not settled, the process and result of learning will not be enhanced. The result will not in line as previously planned. Therefore, it is assumed the problem will be solved if the students worked cooperatively.

Regarding the problem above, therefore, this current work tries to investigate the way to enhance 
students' translation work of both process and result. Some previous studies have been examined this issue. Baihaqi (2018); Baihaqi \& Oktaviani (2019); and Carolia (2019) investigated the result of students' translation work. This present research, meanwhile, tries to investigate the students' translation work of both process and result.

Furthermore, cooperative learning of the Student Team Achievement Division or STAD is applied to enhance both process and result of students' translation works. This is considered important since the study of the Student Team Achievement Division is mainly investigated at the school level, as previous works by Majoka, Dad, \& Mahmood (2010); Tarmon (2017); and Trisnawati (2020). This work, meanwhile, studies the use of the Student Team Achievement Division at the university level.

\section{THEORETICAL REVIEW}

\section{Translation}

The translation is not an easy process as most people think. As Nababan (2003) stated that a good translation has to fulfill some criteria such as accuracy, readability, and acceptability. A translator needs to cope with several processes in his work; this may refer to context, lexical, and grammar (Baihaqi 2017). Whatever the problems, the translators still have some procedures or steps to reproduce the meaning into the target language. In translation, the meaning plays a vital part.

The translators need to know the fact that every language is different. Therefore, translation can serve as an activity that raises students' alertness toward similarities and differences between source and target language linguistic and extra-linguistic structure. The differences of both structures may distort the meaning during the process of translation. A translator must figure out the structure of both source and target language since translation is not simply a matter of language choice, but also culture as well.

As Basnett (2013) stated that translation is a process that involves the delivery of a source language text into the target language to ensure that the surface meaning of the two will be approximately similar and the structures of the SL will be preserved as closely as possible but not so close that the TL structures will be seriously distorted. Hatim \& Munday (2004) 
also proposed three notions on translation; (1) translation is the process of transferring a written text from the source text to target text, conducted by a translator, or translators, in a specific socio-cultural context; (2) the written product, which results from that process and which functions in the socio-cultural context of the TL; and (3) the cognitive, linguistic, visual, cultural and ideological phenomena which are an integral part of one and two.

The above views deliberate on a keyword of translation, which is the equivalence of both linguistic and cultural phenomena. Equivalence refers to the degree of accuracy of both source and target text. The translator's task here refers to how they reproduce the version that linguistically and culturally acceptable.

\section{Cooperative Learning of STAD}

As a type of cooperative learning, Student Teams Achievement Division or STAD is assigned to three to fivemember learning teams. The teams involve high, average, and lowperforming students. Thus, each team serves a miniature of the entire class.

There are five main steps when Student Team Achievement Division is implemented (Slavin, 1990). The steps are presented as follows.
The first is Class Presentation. The teacher delivers the material in front of the class that focuses on the concepts to be discussed. The second is the Formation of Study Groups. Students are managed into groups whose members are heterogeneous. The next is the Provision of tests or quiz to see individual capability without peer support. The fourth is the Individual test to see the result of cooperative activity. This is aimed to examine the improvement reached due to cooperative effort and results that are compared to the previous ones. The last is Awards group or team recognition. The award is given to the group as an appreciation of the efforts that have been made during the class.

It is claimed that the steps of the Student Teams Achievement Division would solve the problems of translation. As Yunus (1992) and Baihaqi (2017) had classified the major problems of translation into linguistics and extra-linguistics.

The linguistics problem is related to the structure and the rule of certain languages consisting of (1) phonological problems which are categorized into two parts: the problems of writing and spelling system; (2) morphological problems 
which refer to the formation of the words; (3) syntactical problems which refer to the rule for sentence building; and (4) lexical problems which refer to the variety of the words.

Non-Linguistic problems, on the other hand, refer to the material and social culture. Different cultures express different kinds of material and things. The word breakfast, for instance, is translated into sarapan in the Indonesian Language. However, breakfast and sarapan refer to the different concept. This example forms problems in translation. In this case, it is hard to find the equivalent terms.

There are also other social culture terms which are untranslatable into a target language. They have no equivalence in a target language. English word Thanksgiving, for example, has no perfect equivalent meaning in the Indonesian Language. Some terms also has no equivalence in English such as local words ngabuburit and blusukan. Other religious-culture terms and ecological names of plants and animals are also impossible to translate.

\section{RESEARCH METHOD}

To solve the problem of this present work, classroom action research was implemented. A classroom action research is a series of cyclical activities. The cycle here was implemented based on Kemmis and McTaggart's Model (2013). They are planning, acting/implementing, observation, and reflection. It was implemented in two cycles.

The subject of the research was students of Translation class from one private university in Banten Province, Indonesia. The class consisted of 15 students. The researchers triangulated by using observation, tests, and documentation for data collecting (Creswell, 2005). The observation sheet was adapted from Ahmad (2015); while the test criteria were adapted from Machali (2000) and Baihaqi (2017). Both were used to examine students' translation works and results.

\section{RESULT AND DISCUSSION}

During the class session, each group consisted of three members, was instructed to translate several sections of the book entitled Kami Pilih Islam written by Bey Arifin. The students enjoyed learning Translation class with Student Teams Achievement Division. Most of them were joyfully involved in translating activities. They did not work individually but cooperated in doing 
the task. They were working in a very comforting atmosphere.

The class atmosphere was tremendously different from the conventional one. They actively participated in learning activities. Some of them were searching for the equivalent or accurate meaning of the words in the Indonesian Language, and some were discussing how to write the equivalent versions.

The researchers ensured all groups' members to work cooperatively. At the end of activities, one of the members was pointed voluntarily to be a representative of the group as a speaker to inform the result of their work to the class.

The researchers stimulated the groups to respond to the questionanswer session. Since they helped each other, they might resolve the problems. Since the group's members were heterogeneous, they helped one another and promote the solution to the problems.

Those subjects' activities above are reflected with the result of the observation below.

Table 1. The Result of Observation in Cycle I

\begin{tabular}{c|l|cccccc|c}
\hline \multirow{2}{*}{ No } & \multicolumn{1}{|c|}{ Statements } & \multicolumn{5}{|c|}{ Groups/Scores* } & \\
& \multicolumn{1}{|c|}{ II } & III & IV & V & \\
\hline 1 & The group members work & 4 & 4 & 4 & 3 & 4 & 3.8 \\
2 & cooperatively. & The group members share and discuss. & 3 & 3 & 3 & 3 & 4 & 3.2 \\
3 & The group members help one another. & 4 & 3 & 3 & 3 & 3 & 3.2 \\
4 & The group members learn happily. & 3 & 3 & 4 & 3 & 4 & 3.4 \\
5 & The group members search for more & 4 & 4 & 4 & 4 & 4 & 4 \\
6 & than one source. & The group members enjoy the learning. & 4 & 3 & 4 & 4 & 3 & 3.6 \\
7 & The group members develop tolerance. & 4 & 3 & 3 & 3 & 3 & 3.2 \\
\hline & & 3.7 & 3.2 & 3.5 & 3.2 & 3.5 & 3.4 \\
\hline
\end{tabular}

Table 2. The Result of Observation in Cycle II

\begin{tabular}{|c|c|c|c|c|c|c|c|}
\hline \multirow{2}{*}{ No } & \multirow{2}{*}{ Statements } & \multicolumn{5}{|c|}{ Groups/Scores* } & \multirow[b]{3}{*}{3.8} \\
\hline & & I & II & III & IV & V & \\
\hline 1 & $\begin{array}{l}\text { The group members work } \\
\text { cooperatively. }\end{array}$ & 4 & 4 & 4 & 3 & 4 & \\
\hline 2 & The group members share and discuss. & 3 & 3 & 4 & 3 & 4 & 3.4 \\
\hline 3 & The group members help one another. & 4 & 3 & 3 & 4 & 4 & 3.6 \\
\hline 4 & The group members learn happily. & 4 & 4 & 4 & 3 & 4 & 3.8 \\
\hline 5 & $\begin{array}{l}\text { The group members search for more } \\
\text { than one source. }\end{array}$ & 4 & 4 & 4 & 4 & 4 & 4 \\
\hline 6 & The group members enjoy the learning. & 4 & 3 & 4 & 4 & 4 & 3.8 \\
\hline 7 & The group members develop tolerance. & 4 & 3 & 4 & 3 & 4 & 3.6 \\
\hline & & 3.8 & 3.4 & 3.8 & 3.4 & 4 & 3.7 \\
\hline
\end{tabular}


* [1] Not implemented yet.

[2] Implemented but not perfect yet.

[3] Almost perfectly implemented.

[4] Perfectly implemented.

The results of the observation above reflect the enhancement of students' translation works as detailed follows.

Chart 1. The Result of Observation

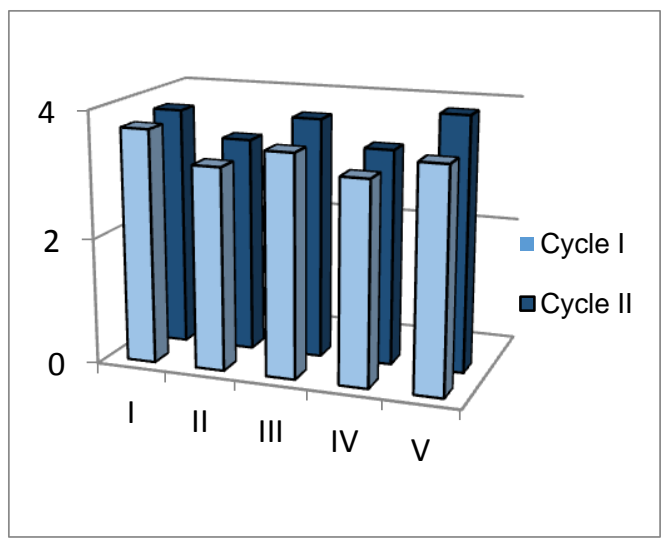

It was recognized that the group members were working cooperatively. They were sharing and discussing both the learning material and the task given. They helped each other and they can run the learning process happily. The result also proves that group members enjoy the learning process and they can develop tolerance among the members.

Since this research was also aiming to investigate the enhancement of students' translation results, the test was also organized from the similar book Kami Pilih Islam written by Bey Arifin. The student was asked individually to translate several paragraphs of the book. The result is presented as follows.

Chart 2. The Result of Test*

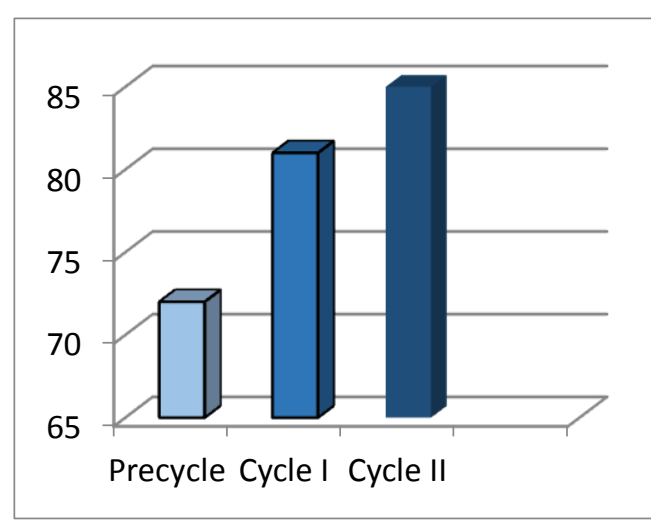

* [20-45] Poor Translation

[46-60] Sufficient Translation

[61-75] Good Translation

[76-85] Very Good Translation

[86-90] Excellent Translation

Regarding the result, the improvement could be realized by examining the grades of the tests before the implementation of the Student Team Achievement Division and those after the implementation of the Student Team Achievement Division. The average score of precycle is 72 while after STAD implementation is 81 in cycle I and 85 in cycle II. It increases by 13 points. Thus, it proves that Student Team Achievement Division can significantly 
enhance students' translation works of both process and result.

Based on the result of both observation and test above, it carries several reflections as follows. First, Student Team Achievement Division is a cooperative technique that emphasis the importance of collaboration among the students, so it is essential to familiarize students for the alertness to this aspect. Second, students are discussing the problems they had. However, they need to be made alert that tolerance is a crucial part. Next, the students were helping another in Student Team Achievement Division. It is important to tell them that help here means supporting the weak on how to learn. Fourth, the scores of students after implementing the Student Team Achievement Division have been enormously improved associated with that previous implementation. The last, Student Team Achievement Division technique is wellrecommended for teaching complex materials. So, the students could learn and support each other.

The results of this work are also in line with the previous study from Ahmad (2015); Clavijo \& Marín (2013); Dagilienè (2012); and Rakhman \& Syatroh (2015) which proved that translation can be learned in various learning model, strategy, and procedure/technique, included cooperative learning. This also proves that translation can be an alternative way of teaching and learning English.

\section{CONCLUSION}

This study concludes that the improvement could be comprehended by examining the grades of the tests prior to and after the implementation of the Student Team Achievement Division. The average score of precycle is 72 while in cycle $I$ is 81 and in cycle II is 85. Both scores are categorized as Very Good Translation results. Therefore, it proves that Student Team Achievement Division can significantly enhance students' translation results.

The result also proves that Student Teams Achievement Division may help students to work cooperatively; they can share and discuss the learning material and task; they can assist each other; then, the class may run in a lively atmosphere. Finally, it proves that Student Teams Achievement Division can significantly enhance students' translation works of both process and result, and it can be served as an alternative way in teaching and learning translation. 
In realizing more comprehensible results, further research is suggested. This can examine other cooperative learning techniques in teaching and learning translation.

\section{REFERENCES}

Ahmad, S. (2009). The impact of prior knowledge of the English Department Students of the Tarbiyah Faculty IAIN Ar-Raniry on their translation class performance. Pencerahan: Jurnal Pendidikan, 6(3), 125-145.

Ahmad, S. (2015). Improving Students' Skills in Translation through Students-Teams Achievement Division (STAD) Technique. Al-Talim Journal, 22 (2), 119-128.

Arifin, B. (1995). Kami Pilih Islam. Surabaya: Pustaka Progresif.

Bassnett, S. (2013). Translation Studies. London: Routledge.

Baihaqi, A. (2017). Penerjemahan dan Kesepadanan dalam Penerjemahan. Pandeglang: Staisman Press.

Baihaqi, A. (2018). Source Language versus Target Language Translation Procedures. Journal of English Language Teaching and Literature (JELTL), 1(1).

Baihaqi, A., \& Mulyana, A. (2021). Reviewing the Result of Machine Translation: A Case for Indonesian Translation Version by Google Translate and IMTranslator. PROJECT (Professional Journal of English Education), 4(1), 1-9.
Carolia, D. (2019). Translation Procedures in Translating Abstracts of Postgraduate Students of Sultan Ageng Tirtayasa University. Journal of English Language Teaching and Cultural Studies, 2(1), 25-38.

Clavijo, B., \& Marín, P. (2013). Identifying translation teaching strategies: An exploratory study. International journal of humanities and social science, 3(21), 71-78.

Creswell, J. W. (2005). Educational Research: Planning, Conducting, and Evaluating, Quantitative and Qualitative Research. New Jersey: Prentice Hall.

Dagilienè, I. (2012). Translation as a learning method in English language teaching. Studies about Languages, (21), 124-129.

Hatim, B., \& Munday, J. (2004). Translation: An advanced resource book. London: Routledge.

Hatim, B. A. (2014). Teaching and Researching Translation. London: Routledge.

Kemmis, S., McTaggart, R., \& Nixon, R. (2013). The Action Research Planner: Doing Critical Participatory Action Research. Singapore: Springer Science \& Business Media.

Machali, R. (2000). Pedoman bagi Penerjemah. Jakarta: PT. Grasindo.

Majoka, M. I., Dad, M. H., \& Mahmood, T. (2010). Student team achievement division (STAD) as an active learning strategy: Empirical evidence from 
mathematics classroom. Journal of Education and Sociology, 4, 16-20.

Nababan, M. R. (2003). Teori Menerjemahkan Bahasa Inggris. Yogyakarta: Pustaka Pelajar.

Ormrod, J. E., Anderman, E. M., \& Anderman, L. H. (2006). Educational psychology: Developing learners.

Rakhman, A., \& Syatroh, I. L. (2015). The Analysis of Students' Team Achievement Divisions (STAD) Used in Learning Practice of Translating and Interpreting. ELTIN JOURNAL, Journal of English Language Teaching in Indonesia, 3(2).

Rogi, S. (2009). Beberapa masalah dalam Penerjemahan. In Seminar held by Department of Germany, Faculty of Literature, Sam Ratulangi University, Menado.

Slavin R. E. (1990). Cooperative Learning: Theory, Research and Practice. Massachusettes: Allen and Bacon.

Tarmon, G. (2017). Upaya Meningkatkan Hasil Belajar Siswa pada Mata Pelajaran Matematika Kelas IV dengan Materi Bangun Datar yang Simetris melalui Metode Cooperative Tipe STAD di SDN Citumenggung 3. Cakrawala Pedagogik, 1(1), 60-77.

Trisnawati, A. M. (2020). Penerapan Metode Student Team Achievement Division untuk Meningkatkan Motivasi Belajar dan Prestasi Belajar PKN siswa. Cakrawala Pedagogik, 4(1), 5664.
Yunus, B. (1992). Beberapa Aspek dan Pedoman Pokok Penerjemahan. Banda Aceh: Universitas Syiah Kuala. 